\title{
Volume 3 - Número 1
}

\author{
REGINALDO PUJOL FILHO* \\ Pontifícia Universidade Católica do Rio Grande do Sul, Porto Alegre, RS, Brasil
}

$\sqrt{ }$ ocês ouvem vozes? E vocês leem vozes?

Pois escutem: aqui está o V3N1 da nossa revista Scriptorium. Nosso dossiê para esta edição propôs a discussão e a reflexão sobre a voz e seus usos, seus recursos, suas possibilidades, seus limites. E muita gente atendeu o chamado. Recebemos contribuições com os mais diversos enfoques: voz de personagens, voz em romances, voz na poesia, vozes roubadas e remixadas, vozes esquecidas, vozes, vozes, variadas vozes.

Diego Grando faz a pergunta "qual é a voz que fala no poema?" e parte em busca dessa reposta em seu estudo Muito além do eu lírico: considerações em torno da voz em poesia; Em A voz do autor: a metaficção na criação de personagens em "Diário para um conto", de Cortázar, Luciana Pastorini Urbim se dedica à voz metaficcional de Julio Cortázar para refletir sobre técnicas e processos; Já Iuri Almeida Müller nos traz Les Gommes, de Alain Robbe-Grillet: vozes de coexistência, atento às vozes do romance em sua relação com o tratamento do tempo e com a constituição da obra. Mas vozes ecoam também em outros campos da criação, longe (ou nem tão longe) de romances, contos e poesias. O artista visual Bruno Moreschi nos traz uma reflexão sobre as vozes criadas para seu projeto Art Book no artigo Enciclopédia polifônica: a construção dos textos e das vozes em Art Book; e Leonardo Villa-Forte vem fazer um remix ao discutir "escrita recreativa" e as possibilidades de um timbre autoral quando se escreve com colagens, edições, apropriações, em Voz e expressão na escrita recreativa; Não se apropriando, mas em diálogo com Villa-Forte, Enéias Farias Tavares também trata de apropriações e recriações (e também da estética "Steampunk) ao refletir sobre sua série Brasiliana Steampunk em sua colaboração Polifonia retrofuturista: a (re)criação de vozes literárias na série Brasiliana Steampunk. Enquanto alguns recriam, outros reencontram: Luís Alberto Paz, em A perfeita ilusão: as personagens e suas relações em A luz no

\footnotetext{
* Escritor. Mestre em Escrita Criativa e doutorando em Escrita Criativa no Programa de Pós-graduação em Letras da Escola
} de Humanidades da Pontifícia Universidade Católica do Rio Grande do Sul (PUCRS). <reginaldo_pujol@yahoo.com.br>. 
subsolo, traz para a discussão Lúcio Cardoso, seus personagens, suas vozes, seus universos.

Saindo do dossiê e das nossas fronteiras, de Chicago chega uma fala colombiana para a Scriptorium. Em nossa sessão livre, Leonardo Gil se debruça sobres as poéticas dos maestros Edgard Allan Poe e Julio Cortázar em seu ensaio Cortázar y Poe, lecturas de los maestros.

As vozes de dois nomes da literatura brasileira se fazem presentes em nossa área dedicada à criação literária. Natália Polesso colabora nesta edição nos oferecendo Movimento, capítulo da sua novela inédita Controle. E Godofredo de Oliveira Neto chega por essas páginas com sua narrativa Sequestro da herança africana.

E as imagens? Elas falam? Aqui sim. E isso pode ser comprovado em nossa capa, uma criação de Nadja Voss a partir da imagem Gabinete particular de Ana Mucks (2016 - vista da instalação - Porto Alegre/RS), de Daiana Schröpel.

Como diria uma das tantas vozes do escritor Marcelino Freire, no conto Trabalhadores do Brasil, eis a pergunta: tá me ouvindo bem? Então ouça: aqui está mais um Scriptorium para você ler, escutar, falar e, por que não, colaborar com a gente.

Até o próximo número.

Boa leitura! 